\title{
Analisis Proksimat dan Organoleptik Penggunaan Ikan Malaja sebagai Pembuatan Kerupuk Kemplang
}

\section{Proksimat and Organoleptik Analysis the use of Fish as Making Crackers Malaja Kemplang}

\author{
Abdul Razak Thaha1, ${ }^{1}$ ainal ${ }^{2}$, St. Khadijah Hamid ${ }^{1 *}$, Denny Saputra Ramadhan ${ }^{3}$, \\ Nasrul $^{4}$ \\ ${ }^{1}$ Fakultas Kesehatan Masyarakat, Universitas Hasanuddin, Makassar \\ ${ }^{2}$ Fakultas Pertanian, Universitas Hasanuddin, Makassar \\ ${ }^{3}$ Jr. Officer CSR Pertamina Sulawesi, Makassar \\ ${ }^{4}$ TBBM Palopo \\ ("khadijah.hmdjjca@gmail.com)
}

\begin{abstract}
ABSTRAK
Ikan Malaja hanya banyak dikonsumsi orang dewasa sehingga perlu upaya agar anak-anak dapat mengonsumsinya di masyarakat Palopo. Kerupuk adalah cemilan yang dapat dimakan disetiap waktu sehingga jika dijadikan kerupuk ikan yang memiliki kandungan gizi yang bermanfaat. Penelitian bertujuan mengetahui uji organoleptik dan proksimat dari kerupuk ikan malaja. Penelitian ini dirancang menggunakan metode eksperimental dengan Rancangan Acak Lengkap faktor tunggal dengan 5 perlakuan dan 3 kali ulangan menjadi 15 unit percobaan. Hasil penelitian menunjukkan bahwa kadar air kerupuk kemplang adalah mulai 1,50-5,12\%. Kadar air tertinggi didapatkan pada perlakuan kontrol. Kadar protein tertinggi dihasilkan dari perlakuan A4. Persentase kadar abu yang tertinggi terdapat pada perlakuan A4 dan terendah pada perlakuan A1. Hasil pengujian menunjukkan bahwa skor aroma yang paling tinggi diperoleh pada perlakuan A1 yakni 3,27. Nilai Skor warna tertinggi diperoleh dari perlakuan A0 (kontrol). Nilai skor rasa tertinggi diperoleh pada perlakuan A2 dan A3. Penambahan ikan malaja sebesar $15 \%$ dan $25 \%$ sangat disukai oleh panelis. Disimpulkan bahwa kandungan tertinggi pada uji proksimat berdasarkan kelompok perlakuan yaitu karbohidrat pada perlakuan, lemak pada perlakuan, protein pada perlakuan A4. Uji organoleptik dengan perlakuan terbaik pada pembuatan krupuk ikan malaja adalah perlakuan A2.
\end{abstract}

Kata kunci : Kerupuk kemplang, ikan malaja

\begin{abstract}
Malaja fish only consumed by adults so it is necessary to make children can consume them in the society of palopo. Crackers are snacks that can be eaten anytime so that if used as fish crackers that contain useful nutrients. This study aims to determine the organoleptic and proximate test of malaja fish crackers. This research was designed using experimental method with Completely Single Randomized Design with 5 treatments and 3 replications to 15 experimental units. The results showed that the water content of kempuk kemplang was from 1.50$5.12 \%$. The highest water content was obtained in the control treatment. The highest protein content is produced from A4 treatment. The highest percentage of ash content was found in A4 treatment and lowest in treatment A1. The test results showed that the highest aroma score obtained at treatment Al ie 3.27. The highest Color Score value is obtained from treatment A0 (control). The highest value of taste scores was obtained in the treatment of $A 2$ and A3. The addition of maladies of $15 \%$ and $25 \%$ is favored by panelists. It was concluded that the highest content in the proximate test was based on the treatment group ie carbohydrate in the treatment, fat in the treatment, protein at treatment A4. Organoleptic test with the best treatment on cracker production of malaja fish is A2 treatment. Keywords : Kemplang crackers, fish malaja
\end{abstract}




\section{PENDAHULUAN}

Ikan merupakan salah satu sumber protein yang kaya senyawa-senyawa yang bermanfaat bagi kesehatan manusia. ${ }^{1}$ Mengonsumsi ikan sangat baik untuk kesehatan. Para ahli menyarankan untuk lebih banyak mengonsumsi ikan dibandingkan daging merah. Ikan sudah tidak asing lagi bagi bangsa Indonesia karena Indonesia kaya akan potensi ikan baik perikanan tangkap maupun perikanan budi daya, sayangnya kesadaran mengonsumsi ikan pada masyarakat masih rendah. Tingkat kosumsi ikan rata-rata per kapita di Indonesia beberapa tahun lalu hanya $23 \mathrm{~kg} /$ orang/tahun sedangkan di Jepang mencapai $110 \mathrm{~kg} /$ orang/tahun. Padahal ikan merupakan sumber protein tinggi, bahkan untuk jenis tertentu kandungan proteinnya lebih tinggi dari daging. ${ }^{2}$

Mayoritas masyarakat menyukai ikan malaja karena rasanya yang enak seperti ikan baronang. Ikan malaja biasa dikonsumsi dengan cara dibakar, digoreng, dibuat lawa (ikan mentah dicuci, difillet, direndam dalam air jeruk bergaram). Ikan malaja dipercaya berkhasiat menaikkan tekanan darah. Ikan malaja merupakan nama lokal dalam bahasa Bugis untuk ikan baronang lingkis. Beberapa nama lokal lain untuk ikan malaja adalah: biahasa (Selayar/Makassar), baluwes (Bajo), dan cangcara (Flores). Ikan malaja dapat diperoleh sepanjang tahun pada habitat karang pada kedalaman 1-3 meter. ${ }^{1}$ Ikan malaja hanya dapat dimakan sebagai menu utama. Sehingga ikan tersebut hanya dapat dinikmati pada waktu-waktu tertentu saja. Oleh karena itu, agar dapat dinikmati kapan saja maka ikan malaja dapat dijadikan kerupuk.

Sebutan kerupuk dibeberapa Negara antara lain krupuk/kerupuk/kropoek di Indonesia, keropok di Malaysia, Kropek di Filiphina, bánh phông tôm di Vietnam merupakan makanan ringan (snack) di beberapa negara Asia. ${ }^{3}$ Kerupuk sudah sedemikian menyatu dengan cara makan sebagian besar masyarakat Indonesia, bahkan ada sebagian keluarga yang mewajibkan menyediakan stok kerupuk di rumahnya. Sensasional kerupuk yang renyah dan gurih membuat makanan makin nikat dan lezat, sehingga mampu meningkatkan selera makan. Di samping menimbulkan sensasi kenikmatan ketika menjadi teman makan, kerupuk juga menjadi makanan cemilan dari banyak orang di Indonesia. ${ }^{4,5}$
Kerupuk ikan pada dasarnya dihasilkan dari percampuran daging ikan dengan pati dan air. Adonan ini kemudian dibentuk menjadi bulat, atau lonjong lalu direbus atau dikukus. Adonan kemudian didinginkan, diiris dan dikeringkan sampai kadar air mencapai 10\%. Irisan dari kerupuk yang sudah kering tersebut kemudian digoreng dengan menggunakan minyak goreng dan biasanya disajikan dalam bentuk makanan ringan atau bersama-sama dengan nasi sebagai lauk-pauk. Selama proses penggorengan, kerupuk menjadi mengembang dan berpori rendah yang disebut pengembangan, ini menjadi salah satu parameter kualitas penting pada krupuk. ${ }^{6}$ Pada proses pengolahan kerupuk, seringkali ditambahkan bahan lain seperti udang, ikan, dan lain-lain untuk meningkatkan citarasa dan kandungan protein pada kerupuk. ${ }^{7}$ Penambahan daging ikan dalam kerupuk ikan diharapkan dapat mempengaruhi karakteristik kimia kerupuk ikan, seperti yang dijelaskan dalam Taewee, bahwa ikan merupakan sumber protein utama dalam pembuatan kerupuk, semakin besar daging ikan yang ditambahkan, maka kandungan protein akan semakin meningkat. ${ }^{8}$

Hingga saat ini kerupuk yang ada dipasaran belum ada yang mengandung gizi yang baik untuk pertumbuhan anak yaitu mengandung protein dan bermacam-macam mineral tinggi. Ikan Malaja memiliki kandungan gizi tersebut, maka jika dijadikan bahan dasar pembuatan kerupuk ikan diharapkan akan meningkatkan gizi khususnya protein dan bermacam-macam mineral tinggi pada kerupuk yang dihasilkan. Ikan malaja belum dimanfaatkan sebagai kerupuk yang dapat dinikmati setiap waktu sehingga menjadi cemilan yang bergizi untuk anak-anak. Kerupuk yang ada dipasaran belum ada yang mengandung gizi yang baik terutama bagi kelompok berisiko seperti bayi, balita, ibu hamil, ibu menyusui oleh karena ikan Malaja mengandung tinggi protein dan bermacam-macam mineral. Namun, sebelum menjadi produk yang dikonsumsi oleh masyarakat, maka perlu dilakukan terlebih dahulu uji proksimat yaitu kandungan gizi dan daya terima melalui uji organoleptik. Berdasarkan pembahasan tersebut, penelitian ini bertujuan untuk melakukan penelitian uji organoleptik dan uji proksimat dalam pemanfaatan ikan malaja sebagai kerupuk kemplang. 


\section{BAHAN DAN METODE}

Penelitian dilaksanakan pada bulan MeiJuli 2017. Bertempat di Fakultas Kesehatan Masyarakat Universitas Hassanuddin, Makassar, Sulawesi Selatan untuk proses pembuatan kerupuk dan uji organoleptik dilakukan di Laboratorium Pengolahan Pangan, Program Studi Ilmu dan Teknologi Pangan Universitas Hassanuddin.

Bahan utama yang digunakan dalam penelitian adalah Ikan malaja yang diperoleh dari Palopo, sedangkan bahan tambahannya digunakan ketumbar, bawang putih, lombok besar, garam halus, masako, terigu, tepung tapioka, ajinomoto dan minyak goreng. Alat yang digunakan dalam pene- litian ini meliputi timbangan, baskom, talenan, pisau, sendok, kompor, tampah, penggorengan, Stop watch, dan pengaduk. Metode yang digunakan dalam penelitian ini adalah experimental laboratories atau metode uji coba. Metode eksperimental dengan menggunakan Rancangan Acak Lengkap (RAL) faktor tunggal dengan 5 (lima) perlakuan dan 3 (tiga) kali ulangan menjadi 5 × $3=15$ unit percobaan. Faktor yang diteliti dalam penelitian ini adalah:

A $0=$ Ikan malaja $0 \%$, tepung tapioka $10 \%$, tepung terigu $90 \%$

A1 $=$ Ikan malaja $10 \%$, tepung tapioka $10 \%$, tepung terigu $80 \%$

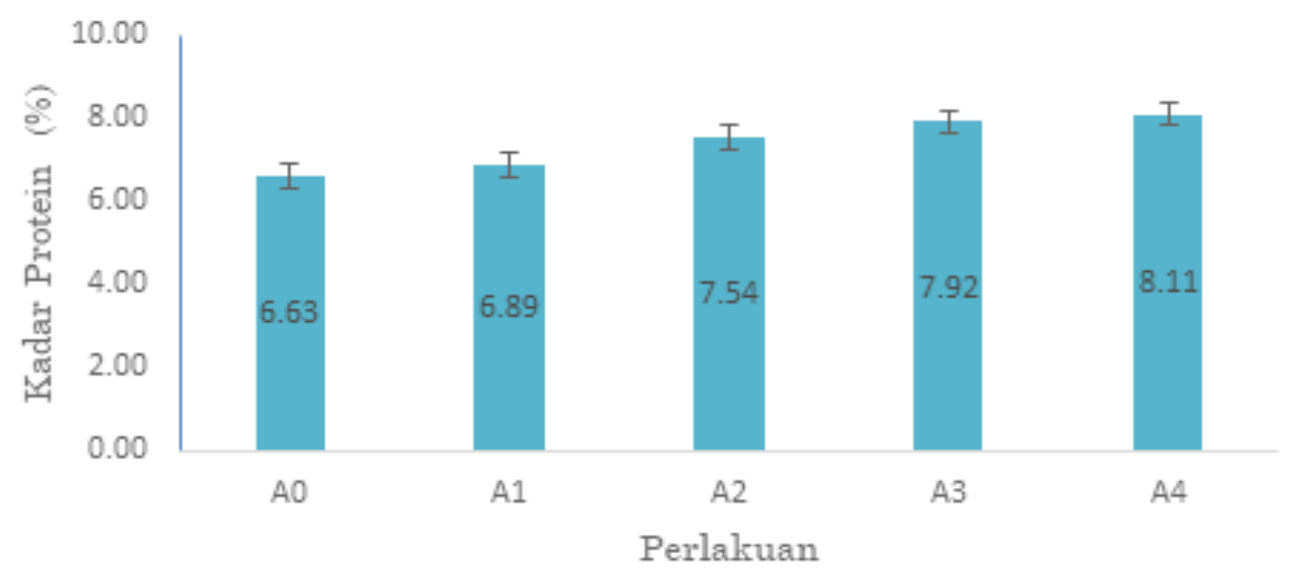

Gambar 1. Kadar Protein Krupuk Kemplang pada Berbagai Perlakuan Penambahan Ikan Malaja

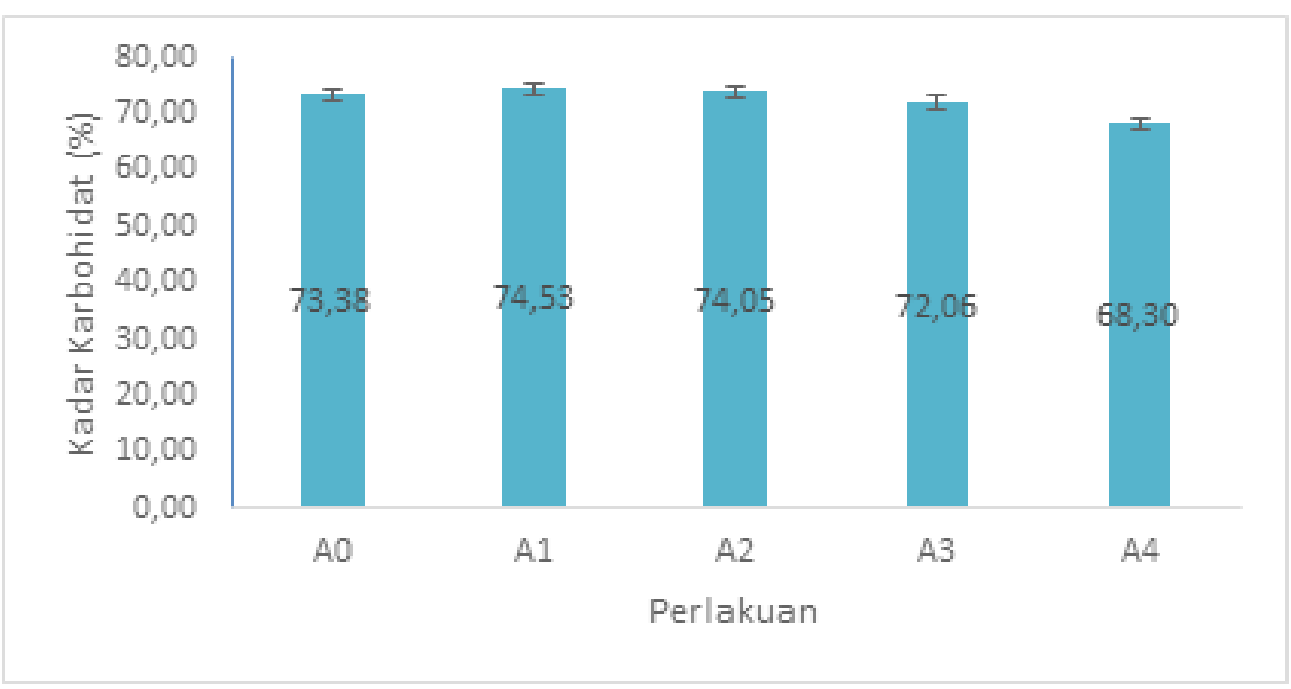

Gambar 2. Kadar Karbohidrat Krupuk Kemplang pada Berbagai Perlakuan Penambahan Ikan Malaja 


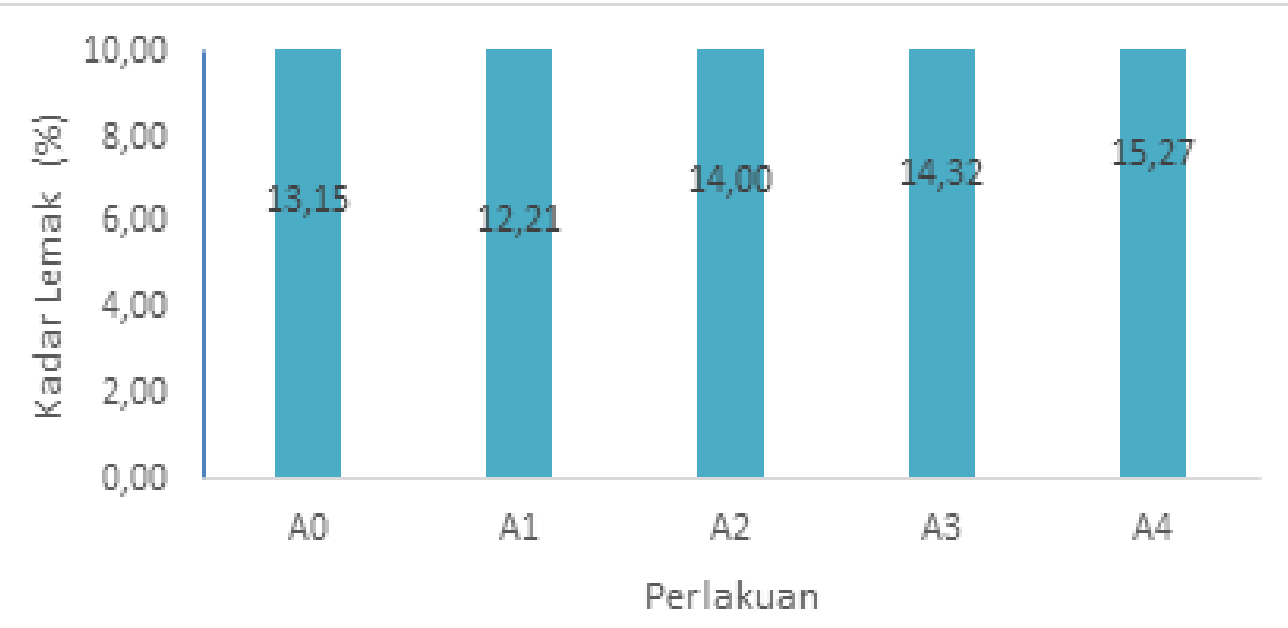

Gambar 3. Kadar Lemak Krupuk Kemplang pada Berbagai Perlakuan Penambahan Ikan Malaja

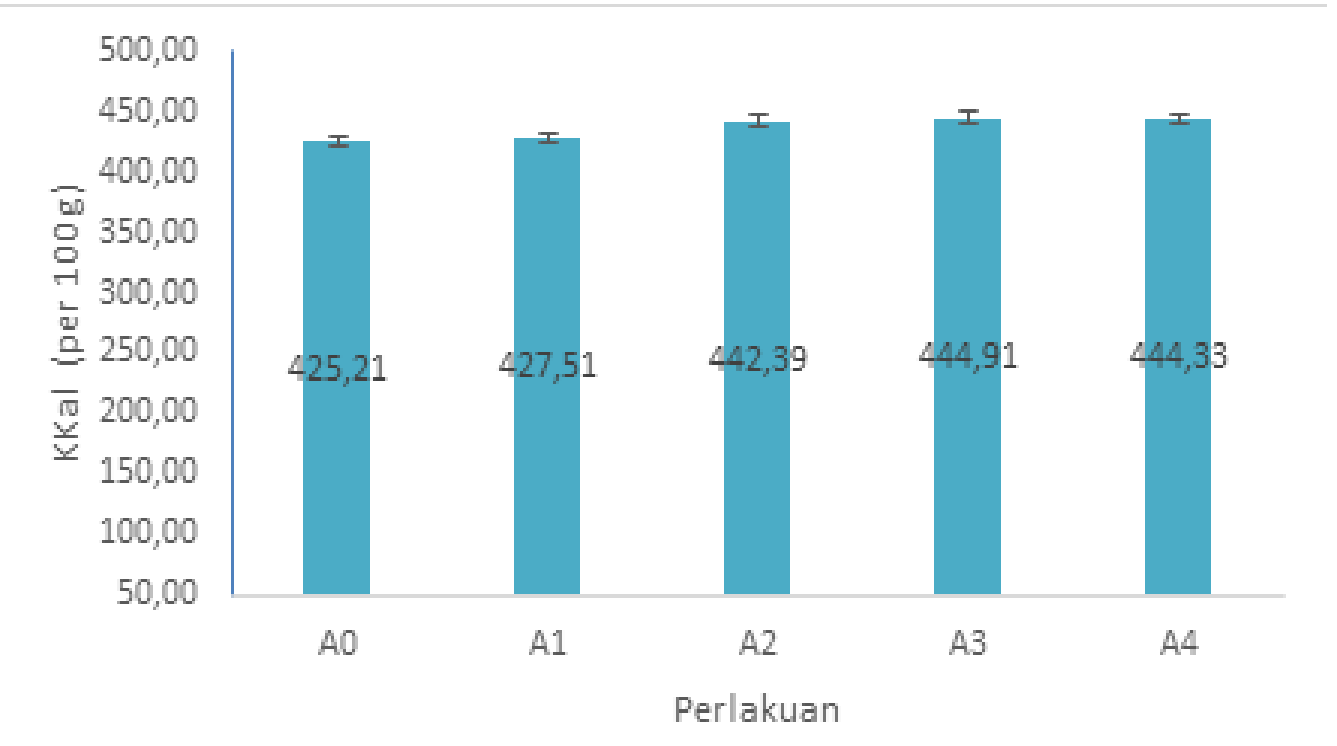

\section{Gambar 4. Nilai Kalori Krupuk Kemplang pada Berbagai Perlakuan Penambahan Ikan Malaja}

A2 $=$ Ikan malaja $15 \%$, tepung tapioka $15 \%$, tepung terigu $70 \%$

A3 $=$ Ikan malaja $25 \%$, tepung tapioka $15 \%$, tepung terigu $60 \%$

A4 $=$ Ikan malaja $30 \%$, tepung tapioka $10 \%$, tepung terigu $60 \%$

Uji proksimat yaitu pengukuran analisis kadar air, kadar abu, karbohidrat, protein, lemak dan kadar mineral. ${ }^{9}$

\section{HASIL}

Gambar 1 menunjukkan bahwa kandu- ngan protein kerupuk kemplang yang berkisar 6,63- 8,11\%. Kadar protein tertinggi dihasilkan dari kerupuk kemplang perlakuan A4 (penggunaa ikan malaja sebesar 30\%). Hasil analisa statistik (uji-t) kadar protein kerupuk berbeda nyata untuk semua perlakukan kecuali antara perlakuan A0 dan A1 ( $\left.\mathrm{F}_{\text {hitung }}>0,05\right)$. Kadar protein memberikan hasil yang signifikan pada menggunaan ikan malaja sebanyak $30 \%$.

Hasil penelitian menunjukkan bahwa perlakuan A4 (A4 = Ikan malaja 30\%, tepung tapioka $10 \%$, tepung terigu $60 \%$ ) memiliki kandu- 


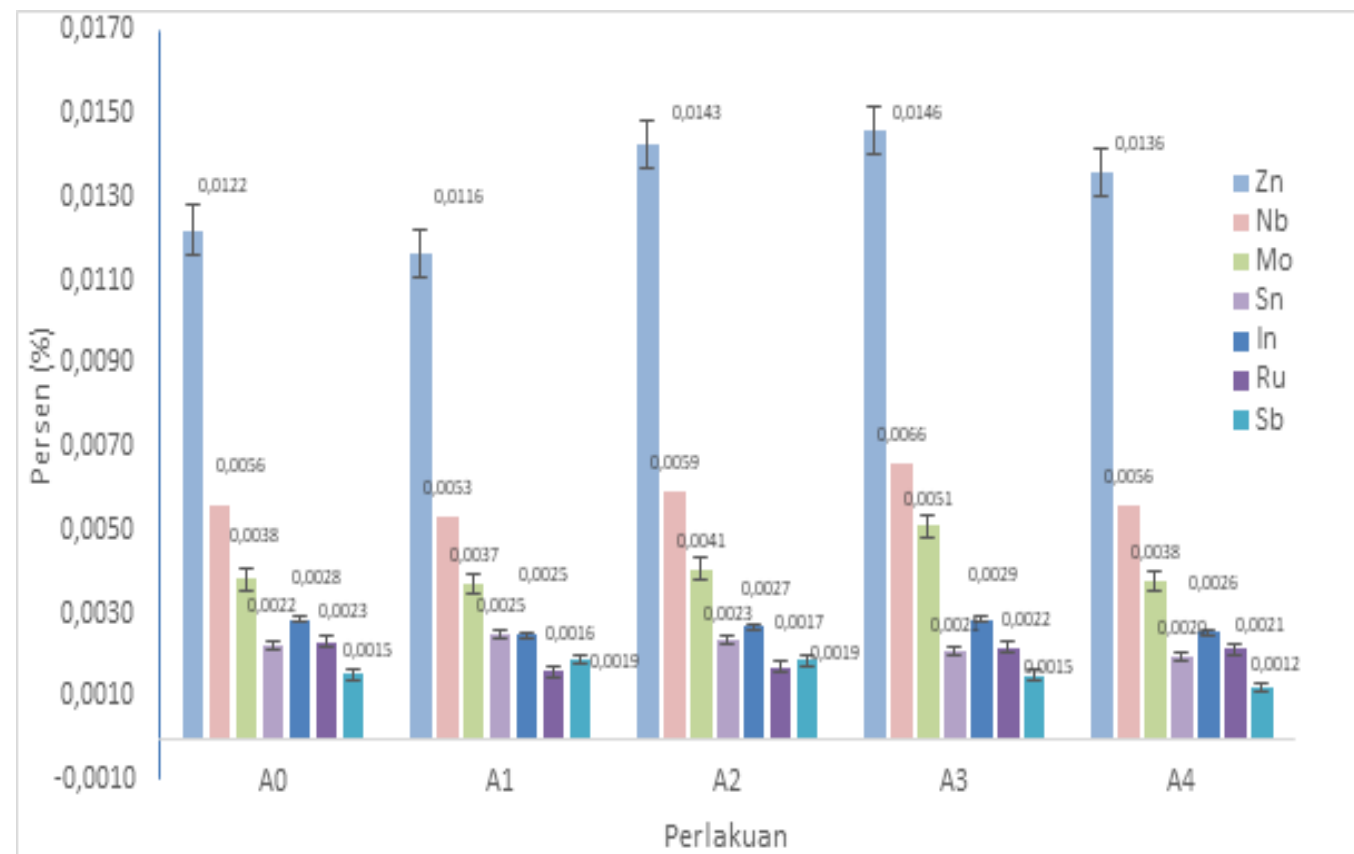

\section{Gambar 5. Kadar Mineral Mikro Krupuk Kemplang pada Berbagai Perlakuan Penambahan Ikan Malaja}

ngan karbohidrat terendah. Hasl uji t menunjukkan bahwa perlakuan A4 berbeda nyata dengan semua perlakuan lainnya (Gambar 2). Gambar 4 menunjukkan bahwa kadar lemak kerupuk kemplang pada berbagai penambahan ikan malaja. Kadar lemak semakin bertambah dengan semakin meningkatnya penambahan ikan malaja. Uji statistik (uji-t) terhadap perlakuan A0 dan A4 memberikan hasil yang berbeda nyata pada $\alpha=0,05\left(\mathrm{~F}_{\text {hitung }}\right.$ $=0,0089$ ).

Kalori kerupuk kemplang ikan malaja dapat dilihat pada Gambar 3. menunjukkan bahwa nilai kalori paling tinggi diperoleh dari perlakuan A4. Hal ini disebabkan perlakuan A4 memiliki kadar lemak yang paling tinggi (Gambar 4.) Hasil uji statistik (uji-t) menunjukkan bahwa perlakuan A0 berbeda nyata dengan semua perlakuan kecuali perlakuan A1, sedangkan perlakuan A2, A3, dan A4 memberikan hasil yang tidak berbeda nyata.

Jumlah dan jenis mineral makro pada kerupuk kemplang dapat dilihat pada Gambar 5. Jenis mineral makro yang ditemukan adalah Klor (Cl), Kalium (K), Kalsium (Ca), dan Pospor (P). Jumlah mineral makro meningkat dengan bertambahnya ikan malaja pada kerupuk kemplang. Hal ini menunjukkan bahwa pemberian ikan dapat menambah kadar mineral makro pada kerupuk kemplang yang dihasilkan.

Jumlah dan jenis mineral mikro pada kerupuk kemplang dapat dilihat pada Gambar 5. Jenis mineral mikro yang ditemukan adalah Zink (Zn), Niobium (Nb), Molybdem (Mo), Timah (Sn), Indium (In), Ruthenium (Ru), danatimon (Sb). Kadar mineral mikro tertinggi diperoleh pada perlakuan A3 (Ikan malaja 25\%, tepung tapioka 15\%, tepung terigu $60 \%$ ), Nilai ini tidak berbeda nyata (uji-t) dengan perlakuan A2 (Ikan malaja 15\%, tepung tapioka $15 \%$, tepung terigu $70 \%$ ) kecuali mineral Sn pada perlakuan A1 dan Ru pada perlakuan A0.

\section{PEMBAHASAN}

Uji kesukaan juga disebut uji hedonik. Panelis dimintakan tanggapan pribadinya tentang kesukaan atau sebaliknya (ketidaksukaan). Selain itu, panelis juga mengemukakan tingkat kesukaannya. Tingkat kesukaan ini disebut skala hedonik, misalnya dalam hal "suka" dapat mempunyai skala hedonic seperti : amat sangat suka, sangat suka, suka, agak suka. Sebaliknya jika tanggapan itu "tidak suka" dapat mempunyai skala hedonic seperti suka dan agak suka, terdapat tanggapannya yang disebut sebagai netral, yaitu bukan suka tetapi juga bukan tidak suka (neither like nor dislike). ${ }^{10}$ Skala hedonik berbeda dengan skala kate- 
gori lain dan responnya diharapkan tidak monoton dengan bertambah besarnya karakteristik fisik, namun menunjukkan suatu puncak (preferency maximum) di atas dan rating yang menurun. ${ }^{11}$

Penilaian tekstur makanan dapat dilakukan dengan jari, gigi, dan langit-langit (tekak). Dari nilai yang diperoleh diharapkan dapat diketahuikualitas makanan. Faktor tekstur diantaranya adalah rabaan oleh tangan, keempukan, kemudahan dikunyah serta kerenyahan makanan. Untuk itu cara pemasakan bahan makanan dapat mempengaruhi kualitas tekstur makanan yang dihasilkan. $^{12}$

Pada penelitian didapatkan perlakuan kontrol memberikan skor tertinggi terhadap kerenyahan dikuti oleh penambahan ikan malaja sebanyak $15 \%$ (perlakuan A2). Nilai berbeda nyata dengan semua perlakuan (uji-t, pada alfa $=0.05$ ). Nilai kerenyahan tertinggi diduga disebabkan oleh kombinasi penggunaan ikan malaja, tepung tapio$\mathrm{ka}$, dan tepung terigu yang proporsional pada perlakuan ini. Pada umumnya kerupuk dikonsumsi sebagai makanan tambahan untuk lauk pauk atau sebagai makanan kecil. Salah satu faktor utama yang menentukan mutu kerupuk adalah kerenyahannya. Semua konsumen menginginkan kerupuk yang renyah, artinya yang menimbulkan bunyi sewaktu digigitdan dikunyah. Kerupuk yang sudah lemas atau lembek dinilai tidak enak lagi. Jadi, sesungguhnya rasa kerupuk menjadi faktor nomor dua yang dinilai konsumen, meskipundi dalam membeli produk makanan tersebut (baik mentah maupun yang sudah digoreng) faktor warna kerupuk tetap menjadi penentu utama bagi konsumen. ${ }^{13}$ Pada penelitian didapatkan bahwa penggunaan ikan malaja yang lebih banyak membuat warna krupuk kurang disukai konsumen. Warna krupuk lebih gelap diakibatkan oleh kulit ikan malaja yang tetap dimasukkan pada saat proses penghancuran ikan dengan blender.

Kadar air merupakan parameter penting produk pangan, terutama produk kering seperti krupuk. Kadar air digunkan untuk megetahui umur simpan kerupuk. ${ }^{7}$ Pada saat bahan pangan dimasukkan ke minyak goreng, air yang terdapat dalam bahan pangan keluar dalam bentuk uap. Kerupuk yang dibuat lebih banyak kanduangan airnya pada A3 sakan tetapi karbohidratnya lebih sedikit setelah A4. Semakin rendah kandungan gizi seperti kadar air, abu, protein, dan lemak maka kandungan karbohidrat semakin meningkat, sebaliknya semakin tinggi kandungan gizi kadar air, abu, protein, dan lemak maka kandungan karbohidrat akan lebih rendah. Kerenyahan pada kerupuk pegagan dipengaruhi oleh kandungan pati. Penambahan bahan bukan pati yang terlalu banyak dapat menurunkan kerenyahan kerupuk. Pati mempunyai dua komponen utama, yaitu amilosa (fraksi terlarut) dan amilopektin (fraksi tidak terlarut), amilopektin merupakan salah satu komponen pati yang dapat mempengaruhi daya kembang kerupuk dan berfungsi memberikan sifat renyah pada kerupuk. ${ }^{14}$

Sesuai dengan pernyataan Hilman yang menyatakan bahwa kadar karbohidrat sangat dipengaruhi oleh faktor kandungan zat gizi lainnya. ${ }^{15}$ Menurut Jayanti, penurunan karbohidrat diduga karena menggunakan cara perhitungan kasar (proximate analysis). Apabila rata-rata kandungan gizi air, abu, protein, dan lemak meningkat, maka akan mengakibatkan nilai karbohidrat menurun, sebaliknya apabila kandungan gizi air, abu, protein, dan lemak menurun, maka akan mengakibatkan nilai karbohidrat meningkat. ${ }^{16}$

Salah satu kandungan gizi penting pada bahan pangan. Bahan utama pembuatan krupuk kemplang adalah tepung terigu. Tepung ini merupakan sumber karbohidrat meskipun memiliki kandungan protein. Penambahan ikan malaja pada krupuk kelmplang bertujuan untuk menambah kandungan protein krupuk kemplang. Hasil ini menunjukkan bahwa dengan penambahan ikan malaja pada krupuk kemplang dapat menambah kandungan protein pada krupuk. Kandungan protein yang tinggi akan membantu anak-anak yang menderita penyakit Kekurangan Kalori Protein (KKP). Hal ini karena ikan merupakan salah satu sumber protein yang baik. Bahkan protein pada ikan merupakan protein yang memiliki asam amino lengkap terutama asam amino essensial. Kalori menunjukkan jumlah energi yang bisa dihasilkan ketika mengonsumsi bahan pangan. Kalori berasal dari zat gizi karbohidrat, protein, dan lemak. Karbohidrat dan protein menghasilkan $4 \mathrm{kkal}$ per gram sedangkan lemak menghasilkan $9 \mathrm{kkal} / \mathrm{gram} .{ }^{17}$

Karbohidrat merupakan sumber kalori utama dalam tubuh manusia. Karbohidrat banyak terdapat dalam bahan pangan nabati. Bahan pa- 
ngan nabati yang merupakan sumber karbohidrat adalah biji-bijian serealia dan umbi-umbian. Jenis serealia yang mengandung karbohidrat adalah beras dan gandum. Gandum kemudian diolah menjadi tepung terigu. Lebih lanjut, jenis umbi-umbian banyak digunakan sebagai sumber karbohidrat adalah singkong. Singkong kemudian diolah menjadi tapioka. Pada pembuatan krupuk kemplang, diantara bahan baku yang digunakan adalah tapioka dan terigu. Bahan-bahan ini membuat kandungan karbohidrat krupuk kemplang cukup tinggi.Kandungan karbohidrat krupuk kemplang yang dihasilkan semakin rendah seiring dengan menurunkan presentase penggunaan tepung tapioka dan terigu pada pembuatan krupuk.

Pada pembuatan krupuk kemplang dengan penambahan ikan malaja, adonan di goreng dengan menggunakan minyak goreng. Minyak pada ikan malaja dan minyak goreng menjadi sumber lemak pada krupuk yang dihasilkan. Kandungan lemak pada penelitian ini memiliki rata-rata kadar sama. Lemak atau minyak merupakan zat makanan yang dibutuhkan oleh tubuh untuk menjaga kesehatan tubuh manusia. Minyak pada bahan pangan dapat berasal dari dalam bahan pangan (internal) maupun dari luar bahan pangan atau sengaja ditambahkan (eksternal). Penambahan metega atau margarin serta proses penggorengan merupakan sumber minyak yang berasal dari luar bahan pangan. Kandungan lemak pada kerupuk pegagan dipengaruhi oleh kerusakan lemak pada proses pemanasan dan beberapa kandungan kimia pada pegagan. Kerusan lemak pada pembuatan kerupuk pegagan diakibatkan karena proses pengukusan dan pengeringan dengan oven. ${ }^{14}$ Menurut Edwar.,et al (2011) bahwa pemanasan dengan suhu tinggi dan lama dapat menyebabkan kerusakan asam lemak tidak jenuh sehingga membentuk asam lemak jenuh dan berbagai jenis gugus radikal bebas. Kandungan ekstrak pegagan seperti asiatikosid, flavonoid dan triterpenoid diketahui memiliki efek antioksidan. Antioksidan dikenal sebagai zat yang dapat menetralisir atau meredam dampak negatif dari radikal bebas. $^{18}$

\section{KESIMPULAN DAN SARAN}

Hasil penelitian ini dapat disimpulkan bahwa dari segi organoleptik (aroma, warna, kerenyakan, dan rasa), perlakuanterbaikpadapembua- tan krupuk ikanmalajaadalahperlakuanA2 (Ikan malaja $15 \%$, tepung tapioka $15 \%$, tepung terigu $70 \%$ ). Produkmemilikikadar air 1,76\%, kadar protein $7,54 \%$, kadarkarbohidrat $74,05 \%$, kadar lemak14\%, nilaikalori 442,39 Kkal/100 g dankadarabu 1,66\%. Selainitu Krupuk kemplangmengandung mineral makro, yaitu Klor $(\mathrm{Cl})$, Kalium $(\mathrm{K})$, Kalsium $(\mathrm{Ca})$, danPospor $(\mathrm{P})$ dan mineral mikroyaituadalah Zink (Zn), Niobium (Nb), Molybdem (Mo), Timah (Sn), Indium (In), Ruthenium $(\mathrm{Ru})$, danatimon $(\mathrm{Sb})$.

Saran bahwa kerupuk ini dapat dikonsumsi oleh masyarakat karena telah melalui uji proksimat yaitu kandungan gizi dan daya terima melalui uji organoleptik. Selain uji organoleptik dan proksimat juga perlu dilakukan uji kadaluarsa agar kerupuk ini dapat dikembangkan dan dipasarkan karena mengandung gizi yang baik yaitu mengandung tinggi protein dan bermacam-macam mineral..

\section{DAFTAR PUSTAKA}

1. Dewi In, Hayati N. Etnoekologi Masyarakat Sekitar Taman Nasional Taka Bonerate dalam Pemanfaatan Kima Lubang (Tridacna Crocea) dan Ikan Malaja (Siganus Canaliculatus). Jurnal Penelitian Kehutanan Wallacea. 2014;3(2):139-149.

2. Atkins C, Robert. Diet Atkins. Jakarta.: PT Elex Media Komputindo Kelompok Gramedia. ; 2007.

3. Amertaningtyas D. Mini Review: Pengolahan Kerupuk "Rambak" Kulit di Indonesia. Jurnal Ilmu-Ilmu Peternakan. 2011;21(3):18-29.

4. Purbomartono C. Pengembangan Produksi Krupuk Ikan Berbahan Dasar Ikan Rucah dan limbah Tahu. Paper Presented At: Proceeding Seminar LPPM UMP2014.

5. Peranginangin R, Soekarto St, Lavlinesia L, Mulianah I. Pengaruh Jenis dan Konsentrasi Daging Ikan Terhadap Pengembangan Volumetrik, Kerenyahan dan Rasa Kerupuk Ikan. Jurnal Penelitian Perikanan Indonesia. 2017;1(2):13-27.

6. Huda N, Leng A, Yee C, Herpandi H. Chemical Composition, Color and Linear Expansion Properties of Malaysian Commercial Fish Cracker ('Keropok'). Asian Journal of Food and Agro-Industry. 2010;3(05):473-482.

7. Ikasari D, Suryaningrum Td, Arti Im, Supriya- 
di S. Pendugaan Umur Simpan Kerupuk Ikan Lele Dumbo (Clarias Gariepinus) Panggang dalam Kemasan Plastik Metalik dan Polipropilen. Jurnal Pascapanen Dan Bioteknologi Kelautan Dan Perikanan. 2017;12(1):55-70.

8. Taewee T. Cracker "Keropok": A Review on Factors Influencing Expansion. International Food Research Journal. 2011;18(3):825-836.

9. Sudarmadji S. Teknik Analisa Biokimiawi. Edisi Pertama. Liberty. Yogyakarta. 1996.

10. Soewarno Ts. Penilaian Organoleptik, Pusat Pengembangan Teknologi Pangan (Pusbangtepa). IPB. Bogor. 1981.

11. Kartika B, Hastuti P, Supartono W. Pedoman Uji Inderawi Bahan Pangan. Universitas Gadjah Mada, Yogyakarta. 1988.

12. Meilgaard Mc, Carr Bt, Civille Gv. Sensory Evaluation Techniques: Crc Press; 2006.

13. Koswara S. Teknologi Pengolahan Singkong: Bogor: Institut Pertanian Bogor; 2009.

14. Nur Aak, Devi M, Hidayati L. Pengaruh Penambahan Pegagan (Centela Asiatica (L.) Urban) Terhadap Daya Terima dan Mutu Kerupuk. Jurnal Aplikasi Teknologi Pangan.
2017;6(3).

15. Hilman N. Studi Kadar Air Hasil Pengeringan Terhadap Mutu Ikan Teri Kering Yang Dihasilkan, Tesis S2.(Tidak Dipublikasikan). Padang: Fakultas Teknologi Pertanian, Universitas Andalas; 2008.

16. Jayanti Ae. Pemanfaatan Flavor Kepala Udang Windu (Penaeus Monodon) Berkalsium Dari Cangkang Rajungan (Portunus Sp.). Bogor: Program Studi Teknologi Hasil Perikanan, Fakultas Perikanan dan Ilmu Kelautan, Institut Pertanian Bogor; 2009.

17. Yuliatmoko W, Satyatama Di. Pemanfaatan Umbi Talas Sebagai Bahan Subtitusi Tepung Terigu dalam Pembuatan Cookies Yang Disuplementasi dengan Kacang Hijau. Jurnal Matematika, Sains, dan Teknologi. 2012;13(2):94-106.

18. Edwar Z, Suyuthie H, Yerizel E, Sulastri D. Pengaruh Pemanasan Terhadap Kejenuhan Asam Lemak Minyak Goreng Sawit dan Minyak Goreng Jagung. Journal of The Indonesian Medical Association. 2011;61(6). 